\title{
ALUMINIUM AND ACID RAIN: MITIGATING EFFECTS OF NaCl ON ALUMINIUM TOXICITY TO BROWN TROUT (SALMO TRUTTA FARIO) IN ACID WATER*
}

\author{
$\nmid$ D. DIETRICH ${ }^{1}$, CH. SCHLATTER ${ }^{1}$, N. BLAU ${ }^{2}$ and M. FISCHER ${ }^{2}$ \\ ${ }^{1}$ Institute of Toxicology, Federal Institute of Technology \& University of Zuerich, \\ CH-8603 Schwerzenbach, Switzerland \\ ${ }^{2}$ Division of Clinical Chemistry, Childrens Hospital, University of Zuerich, CH-8032 \\ Zuerich, Switzerland
}

The comparison of a fish stocking experiment in a Swiss mountain lake (Lake Laiozza) with results obtained in a South Norwegian lake (Lake Liervatn) revealed contradictory results as to the toxicity of the respective acid water. This, even though the $\mathrm{pH}$, aluminium concentration, conductivity, and ionic composition of the two lakes proved to be almost identical. Lake Liervatn water was less toxic and had a substantially higher $\mathrm{NaCl}$ concentration. In order to answer the question whether $\mathrm{NaCl}$ could have a mitigating effect on $\mathrm{pH}$ aluminium toxicity to fish, experiments were performed in the laboratory using "Synthetic Laiozza", a media made up from deionized water and salts added according to the concentrations found in Lake Laiozza. Synthetic Laiozza was then enriched with $0,0.125,0.25,0.5$, and 4.0 meq $\mathrm{NaCl}$ per liter media.

The addition of $0,0.125,0.25$ and $0.5 \mathrm{meq} \mathrm{NaCl} / \mathrm{L}$ had no significant effect on the survival time of the fish (all $\mathrm{MT}_{50}$ 's laying between 16 and 23 hours), whereas the addition of $4.0 \mathrm{meq} \mathrm{NaCl} / \mathrm{L}$ resulted in longer survival of the fish i.e. $\mathrm{MT}_{50}=85$ hours. The analyses of plasma electrolytes on the other hand, revealed a progressive reduction in electrolyte loss with increasing ambient $\mathrm{NaCl}$ concentration.

KEY WORDS: Aluminium, toxicity, mitigation, ionoregulation, $\mathrm{NaCl}$, brown trout, gills, electrothermical atomic absorption spectrometry (ETAAS).

\section{INTRODUCTION}

One and two year old brown trout (Salmo trutta fario) were stocked in the chronically acid Lake Laiozza, a poorly buffered mountain lake in the alps of southern Switzerland. This lake water (labile- $\mathrm{Al}=41-52 \mu \mathrm{g} \mathrm{Al} / \mathrm{L}, 0.5 \mathrm{mg} \mathrm{Ca} / \mathrm{L}, 0.09 \mathrm{mg} \mathrm{Na} / \mathrm{L}$. Conductivity $7 \mu \mathrm{S} / \mathrm{cm}$, and $\mathrm{pH} 5.37 \pm 0.22$ ) proved to be acutely toxic to both age classes $\left(\mathrm{MT}_{50}=37\right.$ hours for one year old fish and 39 hours for the two year old fish respectively). All dying fish had elevated hematocrits (51-81\%) and extremely lowered plasma sodium and chloride concentrations i.e. 63-70 meq Cl/L and 93-109 meq Na/L respectively. ${ }^{1}$ Skogheim and Rosseland, ${ }^{2}$ on the other hand, reported only sublethal

* Presented 13/14 April 1988 at the 3rd IAEAC Workshop on Toxic Metal Compounds, Follonica, Italy. $†$ To whom correspondence should be sent. 
physiological stress in presmolt Salmo salar, a species more susceptible to pH-Al intoxication than Salmo trutta fario, exposed under almost identical conditions in a field experiment in Lake Liervatn, southern Norway. A comparison of Lake Liervatn water with the water of Lake Laiozza revealed a slightly higher Ca concentration and a substantially higher conductivity i.e. $60 \mu \mathrm{S} / \mathrm{cm}$ in Lake Liervatn. The higher conductivity was attributed to the "very high $\mathrm{NaCl}$ concentration in the water". Further evidence as to the possibly mitigating effect of $\mathrm{NcCl}$ on aluminium toxicity to fish was found in Wright and Snekvik's survey on the chemistry and fish population status of over 700 lakes in southernmost Norway. ${ }^{3}$ Of 84 lakes laying in a $10 \mathrm{~km}$ wide south-north transect, all having a $\mathrm{pH}$ equal or lower than $\mathrm{pH} 5.0$, thirty-five are situated within $40 \mathrm{~km}$ of the coastline and have significantly higher $\mathrm{NaCl}$ concentrations than the ones situated in the mountains. The higher $\mathrm{NaCl}$ concentrations seem to mitigate $\mathrm{pH}-\mathrm{Al}$ toxicity, as $63 \%$ of these lakes maintain sparse or good Salmo trutta f. populations, whereas only $27 \%$ of the lakes situated in the mountains i.e. with low $\mathrm{NaCl}$ concentrations are sparsely populated and the rest are barren.

\section{MATERIALS AND METHODS}

All experiments were performed with approx. 2-year-old brown trout (Salmo trutta fario) purchased at a commercially run fish hatchery in Andelfingen, Switzerland. Every experiment was carried out with ten fish and lasted 96 hours or until $50 \%$ of the exposed fish had turned over $\left(\mathrm{MT}_{50}\right)$. The fish were not acclimatized to the experimental conditions with exception for temperature i.e. the fish were exposed to the testing water right after transport. The experimental setup used was a temperaturecontrolled $\left(10 \pm 1^{\circ}\right.$ ) recirculating system (436 liters) with $50 \%$ media renewal every 24 hours. $\mathrm{pH}$ was kept constant by a titration unit coupled with a Metrohm $654 \mathrm{pH}$ meter. Sufficient airation was achieved by reintroducing the water by way of injectors. The exposure media "Synthetic Laiozza" was made up from deionized water adding the necessary ion according to the concentrations found in Lake Laiozza (Table 1).

As soon as a fish had overturned a blood sample was drawn by heart puncture. ${ }^{4}$ The blood samples were analyzed for hematocrit and then centrifuged at 3000 rpm's for 10 minutes in order to separate the plasma. $\mathrm{Na}$ and $\mathrm{K}$ in the plasma were analyzed with the RA-1000 system (Technicon Instruments Corp., USA) using a glass sodiumsensitive electrode and a valinomycin membrane potassium-sensitive electrode.

Table 1 Major constituents measured in Lake Laiozza used for mixing the "Synthetic Laiozza" test media

\begin{tabular}{lclc}
\hline Sodium & $0.09 \pm 0.01 \mathrm{mg} \mathrm{Na} / \mathrm{L}$ & Labile aluminium & $45 \pm 18 \mu \mathrm{g} \mathrm{Al} / \mathrm{L}$ \\
Potassium & $0.20 \pm 0.07 \mathrm{mg} \mathrm{K} / \mathrm{L}$ & Conductivity & $6.7 \pm 0.8 \mu \mathrm{S} / \mathrm{cm}$ \\
Calcium & $0.90 \pm 0.31 \mathrm{mg} \mathrm{Ca} / \mathrm{L}$ & Oxygen & $9.5 \pm 0.3 \mathrm{mg} \mathrm{O} / \mathrm{L}$ \\
Magnesium & $\sim 0.06 \mathrm{mg} \mathrm{Mg} / \mathrm{L}$ & Temperature & $10.0 \pm 1.0^{\circ} \mathrm{C}$ \\
Chloride & $\sim 0.11 \mathrm{mg} \mathrm{Cl} / \mathrm{L}$ & $\mathrm{pH}$ & $5.35 \pm 0.05$ \\
Total aluminium & $105 \pm 9 \mu \mathrm{g} \mathrm{Al} / \mathrm{L}$ & & \\
\hline
\end{tabular}


Chloride was analyzed by coulorimetric titration on an Analyzer 929 (Corning Ltd., $\mathrm{UK}$ ).

The aluminium concentration as well as the $\mathrm{Na}, \mathrm{K}$, and $\mathrm{Ca}$ concentrations in the media were controlled by frequent analysis of water samples using electrothermalatomic absorption spectrometry (ETAAS). Aluminium was speciated basically using the technique described by Barnes ${ }^{5}$ and later modified by LaZerte ${ }^{6}$ though no dialysis or cation exchange resin steps were carried out, but an extra MIBK (Methyl-Isobutyl-Ketone) extraction step introduced in turn. ${ }^{7}$

\section{RESULTS}

\section{Acute toxicity}

Addition of $\mathrm{NaCl}$ to the "Synthetic Laiozza" media significantly increased the $\mathrm{MT}_{50}$ values only when $4 \mathrm{meq} \mathrm{NaCl} / \mathrm{L}$ were added. All other additions did not significantly increase survival time (Figure 1). In order to reproduce these results a retrial was started with additions of 0.5 and $4.0 \mathrm{meq} \mathrm{NaCl} / \mathrm{L}$ respectively. Again a significantly higher $\mathrm{MT}_{50}$ value was recorded for the $4 \mathrm{meq} \mathrm{NaCl} / \mathrm{L}$ addition experiment. The $\mathrm{MT}_{50}$ values of the retrials though were lower than the values reached in the first run (Table 2). This may be explained in part by the higher temperature difference between the rearing temperature and the experimental temperature in the retrials compared to the first run, and thus to a higher temperature acclimatization stress.

Plasma ion loss

In order to compare the ion losses of experiments with different duration i.e. $\mathrm{MT}_{50}$ 's

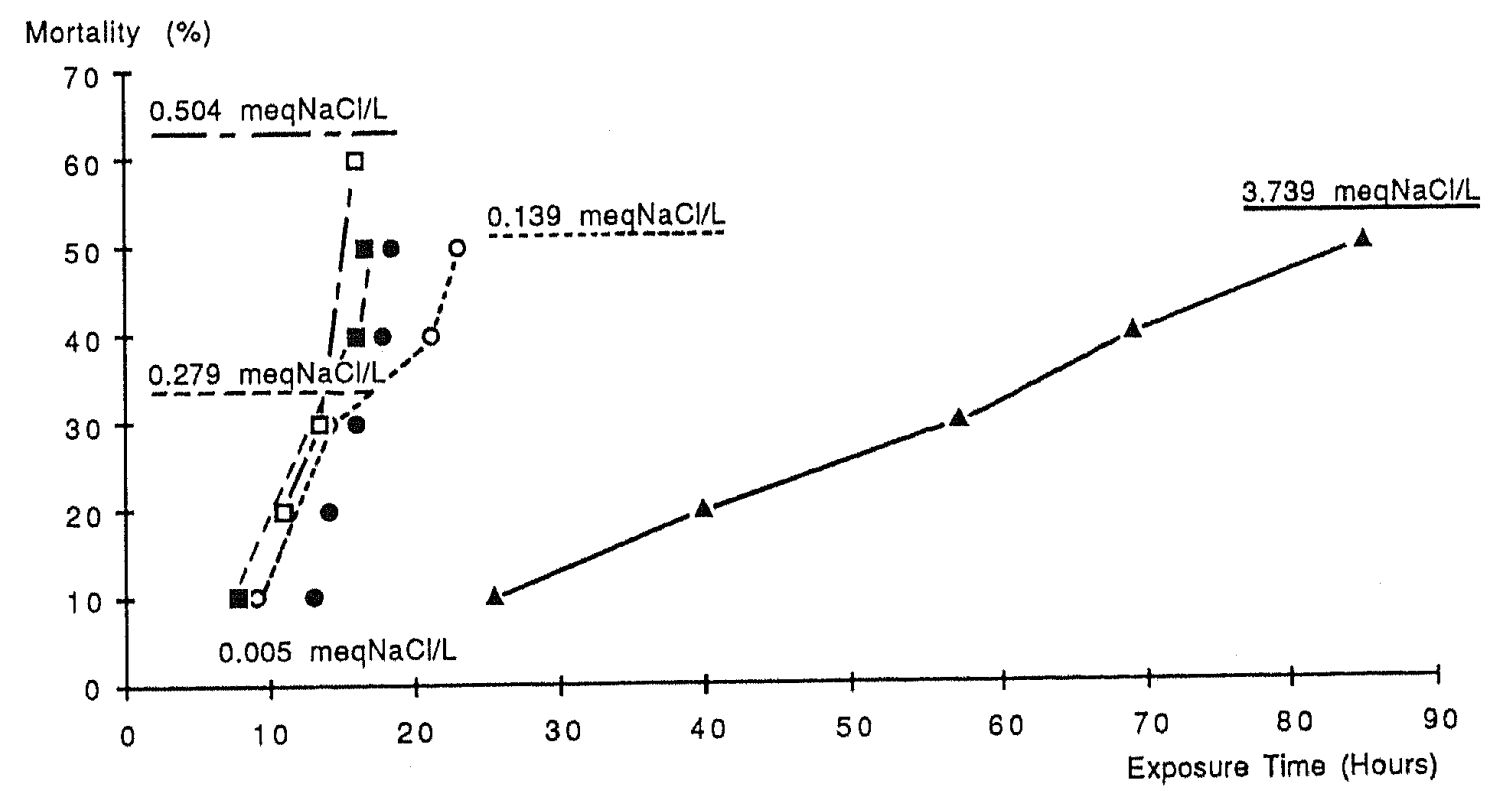

Figure 1 Cumulative mortality of brown trout exposed to $100 \mu \mathrm{g} \mathrm{Al} / \mathrm{L}$ at pH $5.35 \pm 0.05$ vs ambient $\mathrm{NaCl}$ concentrations. 
the respective mean plasma ion concentrations had to be standardized. A "Mean Ion Loss" (MIL) per liter plasma and hour of exposure was calculated:

$$
\mathrm{MIL}=\frac{\mathrm{MNC}-\mathrm{MEC}}{\mathrm{MT}_{50}}
$$

Mean Normal Conc.

(MNC): "Mean plasma ion concentration reported as normal for undisturbed and unexposed fish"

Mean Experimental Conc. (MEC): "Mean plasma ion concentration found in the respective exposures"

Manifestation Time 50\% (MT $\left.{ }_{50}\right)$ : "Time until 50\% of the exposed fish had lost their ability to keep an upright position"

The values used as $\mathrm{MNC}$ were control values taken from fish at the hatchery. These values compared well to values considered as normal in the literature. ${ }^{8,9,10,11}$ A mean value of $160 \pm 10 \mathrm{meq} / \mathrm{L}$ for $\mathrm{Na}$ and $130 \pm 10 \mathrm{meq} / \mathrm{L}$ for $\mathrm{Cl}$ was therefore used for calculations. The addition of $\mathrm{NaCl}$ to the ambient water clearly reduces the net ion loss per hour of exposure (Table 2). The slightly higher ion losses encountered in the second experiment with 0.25 and $0.5 \mathrm{meq} / \mathrm{L} \mathrm{NaCl}$ addition compared to the first experiment with 0 and $0.125 \mathrm{meq} / \mathrm{L} \mathrm{NaCl}$ addition may be explained by small differences in sensitivity of the fish (Figure 2).

In order to compare the hematocrit values recorded in the respective $\mathrm{NaCl}$ additions a standardization with a normal hematocrit of $40 \pm 5 \%{ }^{12}$ had to be carried out in analogy to the MIL calculations, and thus an artificial parameter called Mean Hematocrit Increase (MHI) per hour of exposure was introduced (Table 2). As shown in the MIL calculations, the MHI increases more slowly with increasing ambient $\mathrm{NaCl}$ concentration, possibly reflecting a direct correlation of ion loss to the increase in hematocrit.

Table $250 \%$ mortality, calculated hematocrit increase (MIH), and mean ion loss (MIL) values vs ambient $\mathrm{NaCl}$ concentrations

\begin{tabular}{lccccc}
\hline NaCl additions meq* & 0 & 0.125 & 0.25 & 0.5 & 4.0 \\
\hline MT $_{50}$ (hours) & 18.5 & 23 & 16.5 & 16.0 & 85 \\
MHI \%/hour & 0.973 & 0.652 & 1.030 & 0.813 & 0.165 \\
Mean Na loss/hour & 3.0 & 2.3 & 2.9 & 2.6 & 0.4 \\
Mean Cl loss/hour & 2.8 & 2.1 & 3.0 & 2.9 & 0.5 \\
Repeated assays: & & & & & \\
Mt $_{50}$ (hours) & & & & 11.75 & 30 \\
MHI \%/hour & & & & 0.851 & 0.667 \\
Mean Na loss/hour & & & & 1.7 & 1.4 \\
Mean Cl loss/hour & & & & & 1.7 \\
\hline
\end{tabular}




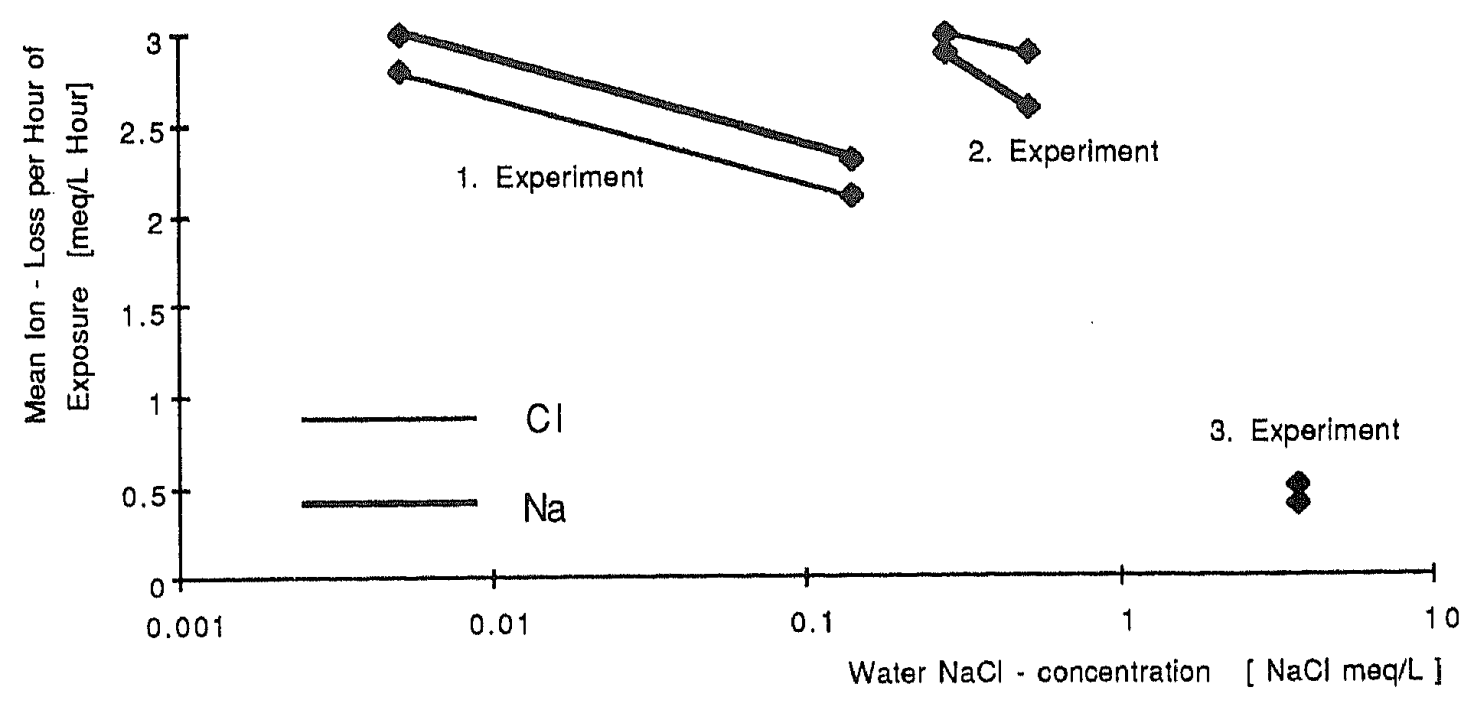

Figure 2 Mean ion loss (MIL) calculated vs ambient $\mathrm{NaCl}$ concentrations.

\section{DISCUSSION}

The mitigating effect of high $\mathrm{NaCl}$-concentrations on $\mathrm{pH}-\mathrm{Al}$ toxicity to fish cannot be explained by the reduction of the $\mathrm{NaCl}$-concentration gradient between plasma and the ambient water, since this gradient of $160 \pm 10 \mathrm{meq} \mathrm{Na} / \mathrm{L}$ plasma to 0.5 and $4 \mathrm{meq}$ $\mathrm{Na} / \mathrm{L}$ water i.e. $130 \pm 10 \mathrm{meq} \mathrm{Cl} / \mathrm{L}$ to 0.5 and $4 \mathrm{meq} \mathrm{Cl} / \mathrm{L}$, respectively, practically remained unchanged. Nor did the analysis of the three major cations i.e. $\mathrm{Na}, \mathrm{K}$, and $\mathrm{Ca}$ throughout the duration of the experiments reveal any substantial variation in concentration such that an experimental bias had to be expected. The ambient $\mathrm{Ca}$ concentration did vary by a maximum of a factor 2 , but higher calcium concentrations i.e. $0.029 \mathrm{meq} \mathrm{Ca} / \mathrm{L}$ were recorded in low as well as high $\mathrm{NaCl}$ addition experiments without any significant influence on the survival times (Table 3).

The speciation of aluminium did not show any significant change in labile-Al concentration, and thus the exposure of the fish to the various Al-species can be considered as being almost identical in all experiments (Table 4). The labile-Al concentration in the first $4 \mathrm{meq} \mathrm{NaCl} / \mathrm{L}$ addition experiment was significantly $(p<0.05)$ lower than in three of the four preceding experiments with lower $\mathrm{NaCl}$

Table $3 \mathrm{NaCl}$ additions vs values analysed in the water samples by ETAAS

\begin{tabular}{lllllll}
\hline $\mathrm{NaCl}$ additions meq/L & & 0 & 0.125 & 0.25 & 0.5 & 4.00 \\
\hline meq/L analysed & $\mathrm{Na}$ & 0.005 & 0.139 & 0.279 & 0.504 & 3.739 \\
& $\mathrm{~K}$ & 0.003 & 0.004 & 0.007 & 0.007 & 0.005 \\
& $\mathrm{Ca}$ & 0.016 & 0.029 & 0.016 & 0.022 & 0.018 \\
\hline Repeated assays: & & & & & & \\
meq/L analysed & $\mathrm{NA}$ & & & & 0.496 & 3.913 \\
& $\mathrm{~K}$ & & & & 0.006 & 0.007 \\
& $\mathrm{Ca}$ & & & & 0.016 & 0.029 \\
\hline
\end{tabular}


Table 4 Aluminium speciation vs ambient $\mathrm{NaCl}$ concentrations. ${ }^{*}$ denotes a significant difference $(\mathrm{p}<0.05$, Wilcoxon, Mann-Whitney 2-tailed U-test) to the corresponding values at lower ambient $\mathrm{NaCl}$ conc.

\begin{tabular}{lccccc}
\hline NaCl additions meq/L & 0 & 0.125 & 0.25 & 0.5 & 4.0 \\
\hline Total $\mathrm{Al} \mu \mathrm{g} / \mathrm{L}$ & $106 \pm 2$ & $103 \pm 13$ & $99 \pm 6$ & $108 \pm 1$ & $107 \pm 12$ \\
$>0.22 \mu \mathrm{m}$ insoluble $\mathrm{Al} \mu \mathrm{g} / \mathrm{L}$ & $36 \pm 19$ & $45 \pm 6$ & $36 \pm 30$ & $34 \pm 22$ & $62 \pm 17$ \\
& & & & & $*$ \\
Labile $\mathrm{Al} \mu \mathrm{g} / \mathrm{L}$ & $60 \pm 18$ & $48 \pm 19$ & $52 \pm 22$ & $67 \pm 21$ & $33 \pm 7$ \\
Repeated assays: & & & & & \\
Total $\mathrm{Al} \mu \mathrm{g} / \mathrm{L}$ & & & & $111 \pm 15$ & $103 \pm 12$ \\
$>0.22 \mu \mathrm{m}$ insoluble $\mathrm{Al} \mu \mathrm{g} / \mathrm{L}$ & & & & $12 \pm 5$ & $26 \pm 23$ \\
Labile $\mathrm{Al} \mu \mathrm{g} / \mathrm{L}$ & & & & $81 \pm 15$ & $63 \pm 23$ \\
\hline
\end{tabular}

addition. This result represents an experimental artefact as the water samples of this experiment were not speciated within the same time as the water samples of all the other experiments. That the aluminium speciation remains the same irrespective of the $\mathrm{NaCl}$ concentrations added can be seen when comparing the speciation of the 4 meq $\mathrm{NaCl} / \mathrm{L}$ retrial with the speciation of the preceding experiments. These observations are corroborated by the findings of Leivestad et al. ${ }^{13}$

It is therefore possible to assume that the effects on survival time found during these experiments are solely due to the $\mathrm{NaCl}$ additions. As the ion efflux from the plasma into the ambient water is a function of the gill permeability, which in turn is controlled by the ambient $\mathrm{Ca}$ concentration and not by the $\mathrm{NaCl}$ concentration, ${ }^{14}$ it can be assumed that the ion efflux rate remained unchanged in all experiments. The measured ion losses per hour reflect the net ion loss per hour i.e. (ion influx -ion efflux). Therefore, a reduction of net ion loss must reflect a change in the ion influx rate. Electrolyte uptake mechanisms e.g. Na-K ATP'ase have been shown to be inhibited in fish exposed to $27 \mu \mathrm{g} \mathrm{Al} / \mathrm{L}$ at $\mathrm{pH} 5.8^{15}$ and to $54 \mu \mathrm{g} \mathrm{Al} / \mathrm{L}$ at $\mathrm{pH} 4.0$ to $4.5 .{ }^{16} \mathrm{~A}$ stimulation of $\mathrm{Na}$ and $\mathrm{Cl}$ uptake or a reduction of $\mathrm{Na}-\mathrm{K}-\mathrm{ATP}^{\prime}$ ase inhibition by competition of $\mathrm{Na}$ or $\mathrm{Cl}$ with aluminium, may be two possible mechanisms by which high ambient $\mathrm{NaCl}$ concentrations could mitigate $\mathrm{pH}-\mathrm{Al}$ toxicity and lead to the reported reductions in ion loss per hour. The latter possibility was already mentioned by Leivestad et al. ${ }^{13}$ who found lower inhibition of Na-K-ATP'ase when $0.3 \%$ sea water were added to experimental waters. Given the assumption that ambient $\mathrm{Ca}$ regulates only the permeability of the gills to water and electrolytes, and that ambient $\mathrm{NaCl}$ concentrations influence electrolyte uptake and/or enzyme inhibition by aluminium, it is likely that the ratio of $\mathrm{NaCl}$ to $\mathrm{Ca}$ concentrations in the ambient water, and not only the Ca-concentration, determines the degree of aluminium toxicity to fish.

\section{ACKNOWLEDGEMENTS}

We are indepted to Anna-Maria Forss for her valuable assistance at the end of the experiments, and to Amadeus Bärtsch for critically reading the manuscript. This 
publication is part of a research project funded by the Swiss National Research Foundation, grant No. 3. 137-0.85.

\section{REFERENCES}

1. D. R. Dietrich, PhD-thesis, 1988.

2. O. K. Skogheim and B. O. Rosseland, Bull. Environ. Contam. Toxicol. 37, 258 (1986).

3. R. F. Wright and E. Snekvik, Verh. Internat. Verein. Limnol. 20, 765 (1978).

4. J. Lehmann and F-J. Stürenberg, Fisch und Umwelt 8, 77 (1980).

5. R. B. Barnes, Chem. Geol. 15, 177 (1975).

6. B. D. LaZerte, Can. J. Fish. Aquat. Sci. 41, 766 (1984).

7. D. R. Dietrich, in preparation (1988).

8. C. M. Neville, Can. J. Fish. Aquat. Sci. 42, 2004 (1985).

9. M. G. Wheatley et al., Respiration Physiology 55, 155 (1984).

10. S. Thomas and G. M. Hughes, Respiration Physiology 49, 371 (1982).

11. D. G. McDonald et al., J. exp. Biol. 88, 109 (1980).

12. J. Lehmann and F-J. Stürenberg, Gewässer und Abwässer (H. Kaltenmeier Söhne, Krefeld-Hüls, 1976), Vol. III, 7.

13. H. Leivestad et al., Annis, Soc. R. Zool. Belg. 177/1, 387 (1987).

14. P. G. McWilliams and W. T. W. Potts, J. comp. Physiol. 126, 277 (1978).

15. H. Kjartansson, PhD-thesis (University of Bergen, Norway, 1984), 93 pp.

16. T. R. K. Dalziel, Annls. Soc. R. Zool. Belg. 177/1, 421 (1987). 